\title{
Manajemen Perencanaan Kemahasiswaan di STAI Darul Kamal NW Kembang Kerang NTB
}

\author{
Sunardi \\ nadhihimmahnw@gmail.com \\ Manajemen Pendidikan Islam, STAI Darul Kamal, Lombok Timur, Indonesia
}

\begin{abstract}
Abstrak
Kemahasiswaan merupakan bagian unsur terpenting dalam penyelenggaraan pendidikan di STAI Darul Kamal. Mahasiswa sebagai pelanggan primer dapat memberikan warna tersendiri bagi sebuah kampus. Tinggi rendahnya animo calon mahasiswa yang mendaftar dapat dijadikan bagian indikator penting yang memberikan kesan bahwa perguruan tinggi tersebut memiliki nilai dan daya saing. Oleh karena itu, manajemen perencanaan kemahasiswaan perlu dirancang dan diimplementasikan secara baik dan sistematis mulai dari tahap sosialisasi, masa pendaftaran (rekrutmen), tes masuk, hingga pada tahap orientasi. Dengan menggunakan pendekatan kualitatif data dikumpulkan melalui teknik wawancara, observasi, dan dokumentasi. Adapun analisis data yang peneliti gunakan adalah analisis non statistik (statistik deskriptif), karena data yang diperoleh dalam penelitian ini bersifat kualitatif, sehingga bisa disusun dan langsung ditafsirkan untuk menyusun kesimpulan penelitian berdasarkan masalah-masalah yang dirumuskan sebelumnya melalui pendekatan induktif. Berdasarkan hasil analisis data dapat disimpulkan bahwa secara umum manajemen perencanaan kemahasiswaan telah dilakukan dengan baik sekalipun belum menunjukkan hasil yang maksimal. Usaha-usaha yang telah dilakukan menunjukkan adanya upaya peningkatan ke arah yang lebih baik.
\end{abstract}

Kata Kunci: Manajemen, Perencanaan Kemahasiswaan

\section{Pendahuluan}

Perguruan tinggi merupakan jenjang pendidikan setelah pendidikan menengah atau setingkat SMA/MA/SMK yang diantaranya program diploma (DI s/d D3), program sarjana(SI), program magister (S2), program doktor (S3), dan program profesi, serta program spesialis, dalam rangka mencerdaskan kehidupan bangsa serta memajukan ilmu pengetahuan dan teknologi.

Mengacu pada UU No 12 Tahun 2012, STAI Darul Kamal sebagai bagian dari sistem Pendidikan nasional memiliki peran strategis dalam mencerdaskan kehidupan bangsa dan memajukan ilmu pengetahuan dan teknologi serta menerapkan nilai humaniora sebagai bentuk pembudayaan dan pemberdayaan bangsa Indonesia. Untuk mewujudkan daya saing bangsa diperlukan perguruan tinggi yang mampu 
Jurnal manajemen dan budaya STAI Darul Kamal NW Kembang kerang

Volume 1 No 2 Tahun 2021

P-ISSN : 2775-1643

E-ISSN : 2774-6704

https://journal.staidk.ac.id/index.php/manajemenbudaya

mengembangkan ilmu pengetahuan dan teknologi sehingga menghasilkan lulusan dan berguna untuk kepentingan bangsa.

Jika berbicara mengenai mutu perguruan tinggi, kualitas pembelajaran dan kemahasiswaan STAI belum mencapai target maksimal. Direktorat Pembelajaran dan Kemahasiswaan pada tahun 2014 menyatakan bahwa akuntabilitas akademik lembaga perguruan tinggi semakin tahun semakin menurun. Hal ini disebabkan tidak konsistennya kualifikasi perguruan tinggi. Selain alasan tuntutan paradigma baru perguruan tinggi global di atas, secara internal, kualitas perguruan tinggi di Indonesia sendiri, terutama perguruan tinggi yang memiliki disparitas yang sangat tinggi.

Untuk menyiapkan itu semua, masalah pertama yang perlu mendapatkan atensi adalah terkait dengan perencanaan manajemen kemahasiswaan. Karena diakui atau tidak, keberadaan mahasiswa dalam sebuah perguruan tinggi menjadi faktor utama bagi hidup matinya sebuah kampus. Sehebat apapun sistem yang dibangun, namun mahasiswa yang mendaftar nihil maka semua itu tidak berarti.

\section{Kajian Pustaka}

Secara lughat kata manajemen berasal dari bahasa latin, yaitu dari asal kata "Manus" yang berarti tangan, dan "Agree" yang berarti melakukan. ${ }^{1}$ Kedua kata itu digabung menjadi manager yang bermakna menangani. Selanjutnya kata manager diterjemahkan ke dalam bahasa Inggris dengan betuk kata kerja "to manage"2 yang “berarti mengatur, mengelola, mengurus." 3 Kamus Webster's New Cooligiate Dictionary menjelaskan bahwa kata manage berasal dari bahasa Italia managgio dari kata managgiare berarti membimbing dan mengawasi, memperlakukan dengan saksama, mengurus perniagaan atau urusana-urusan untuk mencapai tujuan tertentu. ${ }^{4}$

\footnotetext{
${ }^{1}$ Husaini Usman, Manajemen; Teori, Praktik, dan Riset Pendidikan, (Jakarta: Bumi Aksara, 2006).

2 Dengan kata benda "management", dan "manager" istilah yang digunakan untuk orang yang melakukan aktivitas manajemen.

${ }^{3}$ Kamus Inggris Indonesia, Offline.

${ }^{4}$ Imam Machali \& Ara Hidayat, The Handbook of Educationa Management"Teori dan Praktik Pengelolaan Sekolah/Madrasah Di Indonesia, (Prenadamedia: Jakarta: 2016).
} 
Jurnal manajemen dan budaya STAI Darul Kamal NW Kembang kerang

Volume 1 No 2 Tahun 2021

P-ISSN : 2775-1643

E-ISSN : 2774-6704

https://journal.staidk.ac.id/index.php/manajemenbudaya

Dalam Al-Qur'an istilah manajemen adalah pemaknaan dari kata tadbir (pengaturan). Kata ini merupakan derivasi dari kata "dabbara" (mengatur). Seperti dalam firmanNya;

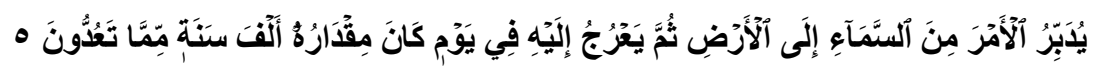

Artinya: Dia mengatur segala urusan dari langit ke bumi, kemudian (urusan) itu naik kepadanya satu hari yang kadarnya (lamanya) adalah seribu tahun menurut perhitunganmu. (QS. As-Sajdah: 5). ${ }^{5}$

Secara istilah para fakar memberikan definisi yang beragam tentang manajemen. Di antaranya definisi yang diberikan Robbins bahwa manajemen adalah "proses mengoordinasikan aktivitas-aktivitas kerja sehingga dapat selesai dengan efisien dan efektif dengan dan melalui orang lain" ${ }^{6}$

Definisi lebih lugas oleh Stoner dan peneliti lebih condong menggunakannya yaitu “proses perencanaan, pengorganisasian, dan penggunaan sumber daya organisasi lainnya agar mencapai tujuan organisasi yang telah ditetapkan".7 Pendapat lain mengatakan bahwa manajemen merupakan "serangkaian proses yang terdiri atas perencanaan (planning), pengorganisasian (organizing), pelaksanaan (actuatuing), pengawasan (controlling), dan penganggaran (budjeting)."8

\section{Ruang Lingkup Manajemen}

Manajemen pendidikan pada dasarnya adalah alat untuk mencapai tujuan pendidikan melalui pengelolaan bidang-bidang pendidikan. Bidang garapan manajemen pendidikan meliputi semua kegiatan yang menjadi sarana penunjang proses belajar mengajar dalam rangka mencapai tujuan pendidikan yang telah ditetapkan.

\footnotetext{
${ }^{5}$ DEPAG RI, Al-Qu'an dan Terjemahannya...

${ }^{6}$ Stephen Robbins/Mary Coulter, Management, edisi 8 jilid 1, (New Jersey, Prentice Hall, 2005).

7 James A.F. Stoner \& Charles Wankel, Management, terj. Bakowatun, $3^{\text {rd }}$ Edition, (New Jersey: Englewood, 1986).

8 Hadari Nawawi, Manajemen Strategic Organisasi Non Profit Bidang Pemerintahan. Yogyakarta: UGM Press, 2000).
} 
Jurnal manajemen dan budaya STAI Darul Kamal NW Kembang kerang

Volume 1 No 2 Tahun 2021

P-ISSN : 2775-1643

E-ISSN : 2774-6704

https://journal.staidk.ac.id/index.php/manajemenbudaya

Substansi yang menjadi garapan manajemen pendidikan sebagai proses atau disebut juga dengan fungsi manajemen pendidikan adalah

1. Perencanaan;

2. Pengorganisasian;

3. Pengarahan, meliputi: motivasi, kepemimpinan, pengambilan keputusan, komonikasi, koordinasi dan negosiasi, serta pengembangan organisasi;

4. Pengendalian, meliputi: pemantauan (monitoring), penilaian, dan pelaporan, monitoring dan evaluasi sering disingkat ME atau Monev. ${ }^{9}$

Gambaran menyeluruh tentang ruang lingkup manajemen pendidikan sebagai proses dapat dijelaskan dalam tabel berikut.

Tabel 1: Ruang Lingkup Fungsi Manajemen

\begin{tabular}{lcccc}
\hline & Planning & Organizing & Actuating & Controlling \\
Man & $\checkmark$ & $\checkmark$ & $\checkmark$ & $\checkmark$ \\
Money & $\checkmark$ & $\checkmark$ & $\checkmark$ & $\checkmark$ \\
Material & $\checkmark$ & $\checkmark$ & $\checkmark$ & $\checkmark$ \\
Methods/media & $\checkmark$ & $\checkmark$ & $\checkmark$ & $\checkmark$ \\
Machines & $\checkmark$ & $\checkmark$ & $\checkmark$ & $\checkmark$ \\
Market & $\checkmark$ & $\checkmark$ & $\checkmark$ & $\checkmark$ \\
Minutes & $\checkmark$ & $\checkmark$ & $\checkmark$ & $\checkmark$ \\
\hline
\end{tabular}

Garapan manajemen pendidikan dalam sebuah sistem manajemen terkait dengan bidang apa saja yang dikelola oleh manajemen untuk mengahsilkan sesuatu yang diinginkan. Manajemen pendidikan mengelola sumber daya-sumber daya (education resources) yang dimiliki oleh organisasi. Sumber daya tersebut dalam sebuah system manajemen pendidikan disebut 7M, meliputi;

1. Man (peserta didik, pendidik, dan tenaga kependidikan;

2. Money (biaya/dana);

9 Husaini Usman, Manajemen; Teori, Praktik... 
3. Materials (bahan, kurikulum, dan informasi);

4. Methods (metode, teknik, strategi);

5. Machines (saran dan prasarana);

6. Market (lulusan, pengguna lulusan/user);

7. Minutes (waktu). ${ }^{10}$

Tabel 2: Ruang Lingkup Tugas Manajemen Pendidikan (Manajemen Sekolah)

\begin{tabular}{|c|c|c|c|c|c|c|}
\hline Tugas & $\begin{array}{l}\text { Peserta } \\
\text { Didik }\end{array}$ & $\begin{array}{l}\text { Tenaga } \\
\text { Pendidikan } \\
\text { dan } \\
\text { Kependidikan }\end{array}$ & Keuangan & $\begin{array}{l}\text { Sarana } \\
\text { dan } \\
\text { Prasarana }\end{array}$ & Humas & $\begin{array}{l}\text { Layana } \\
\text { Khusus }\end{array}$ \\
\hline Perencanaa & $\checkmark$ & $\checkmark$ & $\checkmark$ & $\checkmark$ & $\checkmark$ & $\checkmark$ \\
\hline $\begin{array}{l}\text { Pengorganisa } \\
\text { sian }\end{array}$ & $\checkmark$ & $\checkmark$ & $\checkmark$ & $\checkmark$ & $\checkmark$ & $\checkmark$ \\
\hline Pengarahan & $\checkmark$ & $\checkmark$ & $\checkmark$ & $\checkmark$ & $\checkmark$ & $\checkmark$ \\
\hline Pengendalian & $\checkmark$ & $\checkmark$ & $\checkmark$ & $\checkmark$ & $\checkmark$ & $\checkmark$ \\
\hline
\end{tabular}

\section{Manfaat Manajemen Pendidikan}

Husaini Usman menyebutkan beberapa manfaat manajemen pendidikan, antara lain:

1. Terwujudnya suasana belajar dan proses pembelajaran yang Aktif, Inovatif, Kreatif, Efektif, Dan Menyenangkan (PAIKEM).

2. Terciptanya peserta didik yang aktif mengembangkan potensi dirinya untuk memiliki kekuatan spiritual keagamaan, pengendalian diri, kepribadian, kecerdasan, akhlak mulia, serta keterampilan yang diperlukan dirinya, masyarakat, bangsa dan negara.

${ }^{10}$ Husaini Usman, Manajemen; Teori, Praktik...,4. Dan Imam Machali \& Ara Hidayat, The Handbook..., Baca juga Sunardi Fiqhul, Manajemen Pendidikan Islam Upaya Menggagas Mutu Lembaga Pendidikan Islam, (yogyakarta: Semesta Ilmu, 2020). 
Jurnal manajemen dan budaya STAI Darul Kamal NW Kembang kerang

Volume 1 No 2 Tahun 2021

P-ISSN : 2775-1643

E-ISSN : 2774-6704

https://journal.staidk.ac.id/index.php/manajemenbudaya

3. Terpenuhinya salah satu dari 4 kompetensi tenaga pendidikan dan tenaga kependidikan (tertunjangnya kompetensi professional sebagai pendidik dan tenaga kependidikan sebagai manajer).

4. Tercapainya tujuan pendidikan secara efektif dan efisien.

5. Terbekalinya tenaga kependidikan dengan teori tentang proses dan tugas administrasi pendidikan (tertunjangnya profesi sebagai manajer atau konsultan manajemen pendidikan).

6. Teratasinya masalah mutu pendidikan. ${ }^{11}$

\section{Perencanaan Pendidikan}

Menurut Burhanuddin, istilah perencanaan memiliki pengertian yang beragam, antara lain: perencanaan adalah proses kegiatan pemikiran yang sistematis mengenai apa yang akan dicapai, kegiatan yang harus dilakukan, langkah-langkah, metode, pelaksana yang dibutuhkan untuk menyelenggarakan kegiatan pencapaian tujuan yang dirumuskan secara rasional dan logis serta berorientasi ke depan. ${ }^{12}$ Perencanaan juga bisa diartikan sebagai penetapan tujuan, policy, prosedur, budget, dan program dari suatu organisasi. ${ }^{13}$

Albert Waterston merumuskan perencanaan sebagai "is a on organized intelligent attempt to select the best available alternatives to achieve specific goals" (usaha pemikiran yang teratur guna memilih berbagai alternatif yang tersedia dan terbaik untuk mencapai tujuan tertentu. ${ }^{14}$ Cunningham sebagaimana dikutip Pidarta menyatakan perencanaan adalah menyeleksi dan menghubungkan pengetahuan, fakta-fakta, imajinasi, dan asumsi masa yang akan datang untuk tujuan menvisualisasi dan memformulasi hasil Handbook...

${ }^{11}$ Husaini Usman, Manajemen; Teori, Praktik...,8., Dan Imam Machali \& Ara Hidayat, The

12 Burhanuddin, Analisis Administrasi Manajemen dan Kepemimpinan Manajemen, (Bandung: Mizan, 1994).

13 Dengan fungsi manajemen dalam menetapkan tujuan yang ingin dicapai oleh organisasi, menetapkan peraturan-peraturan, prdoman-pedoman pelaksanaan yang harus dituruti dan menetapkan biaya yang diperlukan, dan pemasukan uang yang diharapkan diperoleh dari tindakan yang dilakukan. Manulang, Dasar-Dasar Manajemen, (Yogyakarta: UGM Press, 2002), 9-10. Imam Machali \& Ara Hidayat, The Handbook...

14 Bintoro Tjokroamijoyo, Perencanaan Pembangunan, (Jakarta: Gunung Agung, 1980). 
Jurnal manajemen dan budaya STAI Darul Kamal NW Kembang kerang

Volume 1 No 2 Tahun 2021

P-ISSN : 2775-1643

E-ISSN : 2774-6704

https://journal.staidk.ac.id/index.php/manajemenbudaya

yang diinginkan, urutan kegiatan yang diperlukan, dan perilaku dalam batas-batas yang yang dapat diterima yang akan digunakan dalam penyelsaian. ${ }^{15}$

Sedangkan menurut Koontz dan O'Donnel sebagaimana dikutip Machali memberikan batasan perencanaan adalah "planning is deciding in advance what to do, how to do it, when to do it and who is to do it, planning bridges the gap from where we wont to go. It makes is possible for thing to occur which would not otherwise happen" (perencanaan adalah suatu proses pemikiran yang rasional dan sistematis apa yang akan dilakukan, bagaimana melakukannya, kapan dilakukan, dan siapa yang akan melakukan kegiatan yang dilakukan untuk meningkatkan mutu sehingga proses kegiatan dapat berlansung efektif, efisien, dan produktif, serta memenuhi tuntutan dan kebutuhan masyarakat. ${ }^{16}$

Terkait dengan definisi di atas, menurut Nawawi perencanaan mempunyai beberapa aspek sebagai berikut:

1) Perumusan tujuan yang hendak dicapai.

2) Penentuan bidang/fungsi/unit sebagai bagian-bagian yang akan melaksanakan kegiatan untuk mencapai tujuan.

3) Menetapkan jangka waktu yang diperlukan.

4) Menetapkan metode atau cara pencapaian tujuan.

5) Menetapkan alat yang dapat dipergunakan untuk meningkatkan efisiensi pencapaian tujuan.

6) Merumuskan rencana evaluasi (penilaian) untuk mengukur tingkat pencapaian tujuan.

7) Menetapakan jumlah dan sumber dana yang dibutuhkan

\section{Metode Penelitian}

Pendekatan penelitian yang digunakan dalam penelitian ini adalah pendekatan kualitatif, sehingga data-data yang terkait dengan masalah dibahas dan dijabarkan

${ }^{15}$ Made Pidarta, Manajemen Pendidikan Indonesia, (Jakarta: Rineka Cipta, 2011).

${ }^{16}$ Imam Machali \& Ara Hidayat, The Handbook...,19-20. Lebih jelas baca Harold Koontz \& Cyril O'Donnel, Principle of Management an Analysis of Managerial Functions, (Tokyo: McGraw Hill Kogakusha, 1972). 
Jurnal manajemen dan budaya STAI Darul Kamal NW Kembang kerang

Volume 1 No 2 Tahun 2021

P-ISSN : 2775-1643

E-ISSN : 2774-6704

https://journal.staidk.ac.id/index.php/manajemenbudaya

secara deskriptif-interpretatif.17 Sedangkan pengumpulan data menggunakan wawancara, observasi, dan dokumentasi.

Adapun analisis data yang peneliti gunakan adalah analisis non statistik (statististik diskriptif), karena data yanng diperoleh dalam penelitian ini bersifat kualitatif, sehingga bisa disusun dan langsung ditafsirkan untuk menyusun kesimpulan penelitian berdasarkan masalah-masalah yang dirumuskan sebelumnya melalui pendekatan induktif.

\section{Pembahasan}

Proses perencanaan manajemen mahasiswa pertama kali diawali dengan menentukan langkah dalam penjaringan calon mahasiswa. Langkah-langkah tersebut di antaranya adalah sosialisasi, rekruitment (penjaringan) dan ujian tes masuk.

Sekolah Tinggi Agama Islam (STAI) Darul Kamal NW Kembang Kerang merupakan salah satu perguruan tinggi swasta yang ada di Lombok Timur dan tergolong masih berumur muda. Menyadari realitas ini, maka untuk tahun pertama sistem penerimaan mahasiswa baru dilakukan melalui pendekatan door to door dan mendekati tokoh yang ditokohkan di masing-masing kampung. Ada dua misi yang terkandung dalam pendekatan ini antara lain; rekrutmen mahasiswa baru dan sosialisasi sekolah tinggi ke masyarakat. Semua civitas akademika dan unsur BP-PTAIS turun ke lapangan untuk sosialisasi.

Rekruitmen mahasiswa STAI Darul Kamal pada hakikatnya adalah proses pencarian, penjaringan, menentukan dan menarik pelamar (calon mahasiswa) untuk menjadi mahasiswa di STAI Karul Kamal. Langkah-langkah rekruitmen mahasiswa baru STAI Darul Kamal adalah:

1. Pembentukan panitia penerimaan mahasiswa baru. Pembentukan ini dilakukan secara musyawarah yang terdiri dari semua unsur Institusi dan Program Studi di lingkungan STAI Darul Kamal, para Dosen, beserta pegawai dan staf akademik.

17 Lexi J. Meleong, Metode Penelitian Kualitatif, (Bandung: Rosda Karya, 2002), dan Koentjoroningrat, Metode-Metode Penelitian Masyarakat, cet. Xi, (Jakarta: Gramedia, 1991). 
Jurnal manajemen dan budaya STAI Darul Kamal NW Kembang kerang

Volume 1 No 2 Tahun 2021

P-ISSN : 2775-1643

E-ISSN : 2774-6704

https://journal.staidk.ac.id/index.php/manajemenbudaya

Susunan kepanitiaan biasanya mencakup: KetuaPanitia, Sekretaris Panitia, Bendahara, dan Anggota/seksi.

2. Pembuatan dan pemasangan pengumuman penerimaan mahasiswa baru secara terbuka. Pengumuman penerimaan mahasiswa baru ini biasanya berisi hal-hal sebagai berikut:

1) Gambaran singkat yang meliputi: Visi Misi institusi dan Program Studi, fasilitas, tenaga pendidik dan kependidikan, dan lain-lain.

2) Persyaratan pendaftaran.

3) Cara pendaftaran.

4) Waktu dan tempat mendaftar.

5) Uang pendaftaran, serta

6) Waktu dan tempat seleksi dan pengumuman hasil seleksi tes masuk. ${ }^{18}$

Ketika panitia penerimaan mahasiswa baru telah terbentuk, selanjutnya panitia tersebut secara otomatis memegang wewenang terkait penjaringan dan pencarian calon mahasiswa baru. Panitia yang sudah dibentuk kemudian melakukan rapat internal dan melengkapi struktur kepanitiaan secara bersama yang tentunya melibatkan semua unsur perguruan tinggi. Setelah panitia terbentuk tahap selanjutnya adalah melakukan publikasi. Publikasi yang dimaksud adalah dengan dengan melakukan sosialisasi baik melalui media online seperti facebook, whatsApp, intagram, dan lain-lain, maupun dengan melakukan kunjungan.

Sistem sosialisasi kunjungan biasanya dialamatkan kepada sekolah atau madrasah dengan sasaran siswa kelas tiga. Dan sekolah-sekolah yang dikunjungi sebagai prioritas utama adalah sekolah yang berada di wilayah STAI dan sekitarnya yang berada di Lombok Timur. Selain melakukan sosialisasi, secara bersamaan panitia penerimaan mahasiswa baru STAI juga melakukan publikasi dengan memasang spanduk dan brosur. "Ketika sosialisasi kami juga lansung membawa brosur. Terutama ketika sosialisasi ke sekolah-sekolah. Selesai sosialisasi kami membagikan brosur kepada para Juni 2021.

${ }^{18}$ Dokumentasi, Pedoman Pelaksanaan Penerimaan Mahasiswa baru, diakses tanggal 21 
Jurnal manajemen dan budaya STAI Darul Kamal NW Kembang kerang

Volume 1 No 2 Tahun 2021

P-ISSN : 2775-1643

E-ISSN : 2774-6704

https://journal.staidk.ac.id/index.php/manajemenbudaya

siswa dan juga kami tempelkan di mading sekolah, tentu ini kami lakukan setelah mendapat izin dari pihak sekolah terkait". ${ }^{19}$

Terkait dengan pemasangan spanduk dan brosur, panitia menjelaskan:

"untuk pemasangan spanduk biasanya kami pasang pada malam hari, karena spanduk kami pasang di jalan raya. Tapi untuk sekarang kami hanya membuat spanduk kecil yang ukuran setengah meter. Itu kami print banyak dan lebih mudah untuk memasangnya karena tidak perlu memanjat seperti pasang spanduk jalan. Untuk spanduk kecil kami hanya pasang di pohon-pohon yang ada di pinggir jalan sehingga tidak mengganggu lalu lalang kendaraan yang melintas". ${ }^{20}$

Selain mengunjungi sekolah-sekolah, panitia penerimaan mahasiswa baru juga mengunjungi beberapa tokoh agama dan masyarakat yang ada di daerah sekitar kampus yang diasumsikan masyarakat dicitrakan sering melakukan pernikahan pada usia muda. Hal ini dimaksudkan untuk memberikan edukasi kepada orang tua wali akan begitu urgennya pendidikan bagi generasi muda.

Di samping melibatkan para dosen, dalam upaya pencarian calon mahasiswa baru STAI juga melibatkan ikatan alumni alumni dan mahasiswa STAI, karena biar bagaimanapun keberadaan mereka bisa memberi pengaruh terhadap upaya pencarian calon mahasiswa. Mereka yang sudah menjadi alumni setelah tamat dari STAI mereka semua pulang ke kampung masing-masing, dan diharapkan mereka bisa mensosialisasikan keberadaan STAI kepada masyarakat sekitar secara umum dan kepada siswa SMA/MA secara khusus. Jadi secara tidak langsung mereka menjadi ujung tombak STAI untuk berinteraksi dengan dunia luar". ${ }^{21}$

Pada tahun akademik berikutnya, sistem rekrutmen akan dilakukan melalui dua jalur yakni penerimaan mahasiswa baru dengan jalur tes dan melalui penjaringan siswa berprestasi (khususnya santri/santriwati yang berprestasi di sebuah Pesantren). Jalur pertama merupakan jalur reguler. Sedangkan jalur penjaringan siswa berprestasi merupakan sistem rekrutmen yang memfokuskan pada pencarian mahasiswa baru berprestasi yang memiliki kemampuan agama yang tinggi di beberapa basis Pesantren

${ }^{19}$ Wawancara, M. Munir pada tanggal 13 Juni 2021.

20Wawancara, M. Munir pada tanggal 13 Juni 2021.

${ }^{21}$ Wawancara, M. Yunus (ketua panitia) pada tanggal 13 Juni 2021. 
Jurnal manajemen dan budaya STAI Darul Kamal NW Kembang kerang

Volume 1 No 2 Tahun 2021

P-ISSN : 2775-1643

E-ISSN : 2774-6704

https://journal.staidk.ac.id/index.php/manajemenbudaya

(khususnya) di wilayah Kabupaten Lombok Timur. Seluruh proses penerimaan mahasiswa baru diselenggarakan oleh sekolah tinggi. Sedangkan peran program studi adalah memberikan informasi dan menentukan jumlah daya tampung program studi bersangkutan. Selain itu, program studi juga melaksanakan proses rekrutmen dan seleksi mahasiswa alih jenjang/program/perpindahan yang hasilnya disahkan oleh sekolah tinggi melalui SK penerimaan dari ketua.

Tahap selanjutnya dalam proses perencanaan ini adalah tahap penerimaan pendaftaran mahasiswa. Pada tahap pendaftaran mahasiswa STAI menerima pendaftaran melalui dua cara atau jalur, yaitu jalur manual dan jalur online. Secara online dilakukan melalui Web yang sudah disediakan dan sudah ada kami tulis di brosur. Calon mahasiswa yang dari jauh bisa mendaftar melalui jalur ini. Di samping itu kami juga membuka jalur manual, mahasiswa bisa datang langsung ke kampus dan panitia penerimaan siap menunggu di tempat pendaftaran". ${ }^{22}$

Calon mahasiswa yang sudah mendaftar selanjutnya dikumpulkan untuk menginformasikan tahapan selanjutnya yaitu seleksi tes masuk sebelum resmi menjadi mahasiswa STAI Darul Kamal. “Mahasiswa yang sudah mendaftar dikumpulkan dan diberikan informasi terkait ujian tes masuk, dan hal itu diinformasikan melalui grup WA yang sudah dibuat untuk mempermudah penyampaian informasi terkait segala hal yang yang berkenaan dengan informasi kampus." 23

Seleksi mahasiswa penting dilakukan terutama bagi Perguruan Tinggi dan Program Studi untuk mendapatkan gambaran umum terkait pengembangan Perguruan Tinggi dan Program studi selanjutnya. Adapun sistem seleksi yang digunakan adalah:

1) Melalui tes atau ujian. Adapun tes ini meliputi tes pengetahuan dasar agama Islam, psikotes, tes akademik atau tes keterampilan.

2) Melalui penelusuran bakat kemampuan. Penelusuran ini biasanya didasarkan pada prestasi yang diraih oleh calon mahasiswa dalam bidang olahraga, keterampilan, dan kesenian.

3) Berdasarkan nilai UN/USBN.

${ }^{22}$ Wawancara, Muhammad Alwan pada tanggal 25 Juni 2021.

${ }^{23}$ Wawancara, M. Alwan Pada tagggal 06 Juli 2021. 
Jurnal manajemen dan budaya STAI Darul Kamal NW Kembang kerang

Volume 1 No 2 Tahun 2021

P-ISSN : 2775-1643

E-ISSN : 2774-6704

https://journal.staidk.ac.id/index.php/manajemenbudaya

Setelah semua dinyatakan lulus, maka mahasiswa bersangkutan diarahkan untuk melakukan registrasi ulang untuk keperluan kegiatan orientasi. Terkait pelaksanaan Orientasi Pengenalan Kampus (OSPEK), STAI menggunakan istilah PriMa (Pekan Orientasi Mahasiswa) STAI. Kegiatan orientasi dilakukan selama tiga hari dengan rincian: dua hari di dalam kampus, dan satu hari di luar kampus. Hal itu diungkap oleh Husairi:

“Kegiatan PriMa biasanya kami lakukan selama tiga hari, dua hari bertempat di kampus, dan satu hari di luar. Kegiatan Prima dikampus dilakukan dengan memberikan materi orientasi sesuai dengan apa yang telah ditetapkan dalam panduan. Secara garis besar meliputi informasi kampus dan akademik, radikalisme, dan wawasan kebangsaan. Sedangkan di luar kampus itu dimaksudkan juga sebagai ajang refreshing dan keakraban di antara mahasiswa dengan melakukan kegiatan-kegiatan yang menyenangkan seperti permainan yang intinya agar mahasiswa tidak bosan. ${ }^{24}$

Jika diperhatikan apa yang dilakukan oleh STAI Darul Kamal maka alur perencanaan manajemen kemahasiswaan meliputi beberapa tahapan:

1. Kebutuhan Peserta Didik ${ }^{25}$

Merupakan kegiatan penetapan mahasiswa yang di butuhkan oleh lembaga pendidikan yang meliputi: (1) Merencanakan jumlah peserta didik yang akan diterima. (2) Menyusun Program kegiatan kemahasiswaan.

2. Rekrutmen Mahasiswa

Pada hakikatnya, proses pencarian mahasiswa yang nantinya akan menjadi mahasiswa STAI Darul Kamal Mengikuti langkah-langkah berikut: (1) membentuk panitia penerimaan mahasiswa yang melibatkan semua unsur dosen dan staf; (2) Pembuatan dan pemasangan pengumuman peserta didik baru(Mahasiswa)

3. Seleksi Mahasiswa.

Merupakan kegiatan pemilihan mahasiswa untuk menentukan di terima atau tidaknya calon mahasiswa menjadi peserta didik di lembaga pendidikan STAI darul kamal di lakukan dengan melalui; (1) Tes atau ujian tertulis;(2)

${ }^{24}$ Wawancara, Husairi pada tanggal 13 Juli 2020.

${ }^{25}$ Tim Dosen AP UPI, Manajemen Pendidikan (Bandung: Alpabeta, 2014). 
Jurnal manajemen dan budaya STAI Darul Kamal NW Kembang kerang

Volume 1 No 2 Tahun 2021

P-ISSN : 2775-1643

E-ISSN : 2774-6704

https://journal.staidk.ac.id/index.php/manajemenbudaya

Melalui penelusuran bakat dan kemampuan mahasiswa;(3) Berdasarkan Nilai UN.

4. Orientasi Mahasiswa. ${ }^{26}$

Merupakan wahana mengenalkan situasi dan Kondisi lembaga pendidikan tempat mahasiswa menempuh pendidika. Lingkungan yang di maksud adalah lingkungan fisik dan lingkungan sosial sekolah, Tujuan orientasi tersebut adalah agar mahasiswa mengerti dan menaati peraturan yang berlaku di lembaga pendidikan. Dan juga mahasiswa dapat aktif dalam kegiatan yang di selenggarakan sekolah, dan siap menghadapi lingkungan baru secara fisik, mental maupun emosional.

5. Penempatan Mahasiswa

Adalah pengelompokan mahasiswa yang dilakukan dengan sistem kelas. Pengelompokan mahasiswa bisa dilakukan dengan Jurusan atau program studi yang dipilih oleh mahasiswa.

Selain itu, dalam melakukan perencanaan manajemen kemahasiswaan, STAI dapat melakukannya dengan langkah sebagaimana disebut Smith (1982) sebagaimana dikutip Usman menyebutkan secara umum terdapat sembilan metode perencanaan pendidikan, yaitu:

1. Analisi Sumber- Cara-Tujuan (Mean-Ways-Goal Analysis)

Metode ini dipakai untuk meneliti sember-sumber dan alternatif mncapai tujuan tertentu. Tiga faktor yang perlu dianalisis yaitu, 1) sumber, 2) cara untuk mencapai tujuan, dan 3) tujuan. Ketiga faktor ini dikaji secara timbal balik.

2. Analisis Masukan-Keluaran (Input-Output Analyssis)

Metode ini dipakai untuk mengkaji faktor-faktor input pendidikan yang mempengaruhi proses dan akibatnya terhadap keluaran secara interelasi dan interdepedensi.

3. Analisis Ekonometrik (Ekonometric Anlysis)

26Tim Dosen AP UPI, Manajemen Pendidikan. 
Jurnal manajemen dan budaya STAI Darul Kamal NW Kembang kerang

Volume 1 No 2 Tahun 2021

P-ISSN : 2775-1643

E-ISSN : 2774-6704

https://journal.staidk.ac.id/index.php/manajemenbudaya

Metode ini memakai data empiris, statistik,dan teori ekonomi dalam mengukur pertumbuhan dalam hubungannya dengan ekonomi. Metode ini dekat dengan pendekatan untung rugi. Metode ini menggunakan persamaan yang mendeskripsikan hubungan interdepedensi variable-variabel yang ada dalam suatu sistem.

4. Diagram Sebab-akibat (Cause- Effek Diagram) ${ }^{27}$

Metode ini dipakai dalam perencanaan yang menggunakan sekuenhiporetik (dugaan) untuk mendapatkan gambaran masa depan. Metode ini mirip dengan perencanaan stratejik.

5. Delphi

Metode ini dipakai untuk menentukan sejumlah alternatif program, mendapatkan asumsi atau fakta yang melandasi pertimbangan tertentu dengan mencapai informasi yang dibutuhkan untukmencapai konsensus. Dimuli dengan mengemukakan suatu masalah umum kemudian dijabarkan secara khusus untik dipecahkan masing-masing ahlinya.

6. Heuriatic

Metode ini dipakai untuk mendapatkan isu-isu dan mengakomodasi pendapat yang bertentangan. Metode ini didasarkan atas prinsip dan prosedur yang mensistematiskan langkah-langkah pemecahan masalah.

7. Analisis Siklus Kehidupan (Life-cycle Analysis )

Metode ini dipakai untuk mengalokasikan sumber daya dengan memerhatikan siklus kehidupan produksi (lulusan), proyek, program, dan kegiatan pendidikan. Tahapannya meliputi 1) konseptualisasi, 2) spesifikasi, 3) pengembangan prototype, 4) pengujian dan evaluasi, 5) operasi, dan 6) produksi (lulusan).

8. Analisis Nilai Tambah (Value Added Analysisi)

Metode ini dipakai untuk mengukur keberhasilan peningkatan lulusan atau pelayanan pendidikan sehingga diperoleh gambaran kontribusi aspek tertentu terhadap aspek lainnya. Metode ini mirip dengan teori incremental. Sebagai

${ }^{27}$ Husaini Usman, Manajemen: Teori, Praktik, Dan Riset Pendidikan (Jakarta: Bumi Aksara, 2006). 
Jurnal manajemen dan budaya STAI Darul Kamal NW Kembang kerang

Volume 1 No 2 Tahun 2021

P-ISSN : 2775-1643

E-ISSN : 2774-6704

https://journal.staidk.ac.id/index.php/manajemenbudaya

tambahan, metode yang paling banyak dalam perencanaan pendidikan tingkat mikro adalah metode ini.

9. Proyeksi

Perencanaan pendidikan dengan metode proyeksi yang menghasilkan metode pemecahan penduduk lima tahun, data persekolah, proyeksi penduduk dan penduduk usia belajar, proyeksi mahasiswa, proyeksi ruang belajar (kuliah), dan proyeksi kebutuhan dosen. ${ }^{28}$

\section{Kesimpulan}

Perencanaan manajemen kemahasiswaan STAI darul kamal nw kembang kerang dilakukan dengan melalui beberapa tahapan. Tahapan pertama dengan melakukan pembentukan panitia penerimaan mahasiswa baru yang lansung di-SK-kan oleh ketua STAI. Setelah panitia terbentuk, tahap selanjutnya adalah sosialisasi penerimaan calon mahasiswa baru yang dilanjutkan dengan penerimaan pendaftaran. Kemudian dilakukan ujian tes masuk dan orientasi.

Dengan demikian, secara umum perencanaan manajemen kemahasiswaan telah dilakukan dengan baik sekalipun belum menunjukkan hasil yang maksimal. Namun dengan usaha-usaha yang telah dilakukan menunjukkan adanya upaya peningkatan ke arah yang lebih baik.

\section{Daftar Referensi}

Burhanuddin, Analisis Administrasi Manajemen dan Kepemimpinan Manajemen, (Bandung: Mizan, 1994).

DEPAG RI, Al-Qu'an dan Terjemahannya ,, 331.

Fiqhul, Sunardi, Manajemen Pendidikan Islam Upaya Menggagas Mutu Lembaga Pendidikan Islam, (yogyakarta: Semesta Ilmu, 2020).

Koontz, Harold, dan O'Donnel, Cyril, Principle of Management an Analysis of Managerial Functions, (Tokyo: McGraw Hill Kogakusha, 1972).

Machali, Imam, dan Hidayat, Ara, The Handbook of Educationa Management"Teori dan Praktik Pengelolaan Sekolah/Madrasah Di Indonesia, (Prenadamedia: Jakarta: 2016)

${ }^{28}$ Husaini Usman, Manajemen: Teori, Praktik, Dan Riset... 
Jurnal manajemen dan budaya STAI Darul Kamal NW Kembang kerang

Volume 1 No 2 Tahun 2021

P-ISSN : 2775-1643

E-ISSN : 2774-6704

https://journal.staidk.ac.id/index.php/manajemenbudaya

Meleong, Lexi J., Metode Penelitian Kualitatif (Bandung: Rosda Karya, 2002)

Nawawi, Hadari, Manajemen Strategic Organisasi Non Profit Bidang Pemerintahan. (Yogyakarta: UGM Press, 2000).

Pedoman Penerimaan Mahasiswa Baru STAI Darul Kamal NW Kembang Kerang NTB 2021.

Pfeffer, Jeffrey, Paradigma Baru Manajemen Sumber Daya Manusia (Yogyakarta: Amara Books, 2003).

Pidarta, Made, Manajemen Pendidikan Indonesia, (Jakarta: Rineka Cipta, 2011).

Robbins, Stephen dan Coulter, Mary, Management, edisi 8 jilid 1, (New Jersey, Prentice Hall, 2005).

Stoner, James A.F., dan Wankel, Charles, Management, terj. Bakowatun, 3 ${ }^{\text {rd }}$ Edition, (New Jersey: Englewood, 1986).

Sudaryono, Educational Research Methodology Panduan Lengkap: Teori, Aplikasi, dan Contoh Kasus. (Jakarta: Lentera Ilmu, 2014)

Sugiyono, Metode Penelitian Pendidikan (Kuantitatif, Kualitatif, Kombinasi, RED dan Penelitian Pendidikan. (Bandung: Alpabeta, 2019)

Sutrisno, Edy, Manajemen Sumber Daya Manusia (Jakarta: Prenada Media, 2016)

Tim Dosen AP UPI, Manajemen Pendidikan (Bandung: Alpabeta,2014)

Tjokroamijoyo, Bintoro, Perencanaan Pembangunan, ( Jakarta: Gunung Agung, 1980).

Usman, Husaini, Manajemen: Teori, Praktik, Dan Riset Pendidikan (Jakarta: Bumi Aksara, 2006) 